\title{
Modified Local Soil (MLS) Technology for Harmful Algal Bloom Control, Sediment Remediation, and Ecological Restoration
}

\author{
Gang Pan ${ }^{1,2,3,4,5,6, *}$, Xiaojun Miao ${ }^{1,2}$, Lei Bi ${ }^{1}$, Honggang Zhang ${ }^{1}{ }^{\mathbb{D}}$, Lei Wang ${ }^{1}$, Lijing Wang ${ }^{1,5}$, \\ Zhibin Wang ${ }^{1,5}$, Jun Chen ${ }^{1,2}$, Jafar Ali ${ }^{1,2}{ }^{-}$, Minmin Pan ${ }^{1,6,7}$, Jing Zhang ${ }^{1}$, Bin Yue ${ }^{3,4,8}$ and \\ Tao Lyu 3,4,*(D) \\ 1 Research Center for Eco-Environmental Sciences, Chinese Academy of Sciences, Beijing 100085, China; \\ miaoxiaojun22@126.com (X.M.); leibi@rcees.ac.cn (L.B.); hgzhang@rcees.ac.cn (H.Z.); leiwang@rcees.ac.cn (L.W.); \\ wanglijing@basic.cas.cn (L.W.); wangzhibin@basic.cas.cn (Z.W.); 13426003723@126.com (J.C.); \\ jafaraliqau@gmail.com (J.A.); panminmin@hotmail.com (M.P.); jingzhang@rcees.ac.cn (J.Z.) \\ 2 University of Chinese Academy of Sciences, Beijing 100049, China \\ 3 School of Animal, Rural, and Environmental Sciences, Nottingham Trent University, Brackenhurt Campus, \\ Nottinghamshire NG25 0QF, UK; bin.yue@ntu.ac.uk \\ 4 Centre of Integrated Water-Energy-Food studies (iWEF), Nottingham Trent University, \\ Nottinghamshire NG25 0QF, UK \\ 5 Beijing Advanced Sciences and Innovation Center, Chinese Academy of Sciences, Beijing 101407, China \\ 6 Sino-Danish College of University of Chinese Academy of Sciences, Beijing 100049, China \\ 7 Department of Environmental Engineering, Technical University of Denmark, DK-2899 Lyngby, Denmark \\ 8 College of Geography and Environmental Engineering, Lanzhou City University, Lanzhou, Gansu 730070, China \\ * Correspondence: gang.pan@ntu.ac.uk (G.P.); tao.lyu@ntu.ac.uk (T.L.)
}

Received: 10 May 2019; Accepted: 25 May 2019; Published: 29 May 2019

check for updates

\begin{abstract}
Harmful algal blooms (HABs), eutrophication, and internal pollutant sources from sediment, represent serious problems for public health, water quality, and ecological restoration worldwide. Previous studies have indicated that Modified Local Soil (MLS) technology is an efficient and cost-effective method to flocculate the HABs from water and settle them onto sediment. Additionally, MLS capping treatment can reduce the resuspension of algae flocs from the sediment, and convert the algal cells, along with any excessive nutrients in-situ into fertilisers for the restoration of submerged macrophytes in shallow water systems. Furthermore, the capping treatment using oxygen nanobubble-MLS materials can also mitigate sediment anoxia, causing a reduction in the release of internal pollutants, such as nutrients and greenhouse gases. This paper reviews and quantifies the main features of MLS by investigating the effect of MLS treatment in five pilot-scale whole-pond field experiments carried out in Lake Tai, South China, and in Cetian Reservoir in Datong city, North China. Data obtained from field monitoring showed that the algae-dominated waters transform into a macrophyte-dominated state within four months of MLS treatment in shallow water systems. The sediment-water nutrient fluxes were substantially reduced, whilst water quality (TN, TP, and transparency) and biodiversity were significantly improved in the treatment ponds, compared to the control ponds within a duration ranging from one day to three years. The sediment anoxia remediation effect by oxygen nanobubble-MLS treatment may further contribute to deep water hypoxia remediation and eutrophication control. Combined with the integrated management of external loads control, MLS technology can provide an environmentally friendly geo-engineering method to accelerate ecological restoration and control eutrophication.
\end{abstract}

Keywords: harmful algal blooms (HABs); eutrophication; internal loads control; oxygen nanobubble; shallow lakes; deep water hypoxia 


\section{Introduction}

Harmful algal bloom (HAB) is one of the detrimental consequences of eutrophication in water bodies, which may pose serious threats to water quality, human and animal health, economic development, ecological balance, landscape aesthetics, and even social stability [1]. The cause of the HABs is complex, and can be mainly due to agriculture, industrial, and other anthropogenic activities, which cause an ever-increasing amount of nutrients to run off from inlands into natural waters [2]. Hence, the mitigation of the problem is complicated, and integrated management is often essential. External loads control and integrated basin management have been demonstrated to be important practices to prevent the continuous input of nutrients from land into water [3]. However, when external loads are under control, the internal loads from polluted sediment often limit the improvement of water quality [4], and the latter is becoming compulsory in many countries by local governance or environmental law. Consequentially, in some countries such as China, this has triggered a large environmental market which is initially driven by government investments and followed by the private sector. The natural restoration of lake ecology or water quality is often a lengthy process that is far beyond the scope of the targets set within one government's term. In this regard, geo-engineering materials, such as modified clays or soils, may accelerate the improvement of water and sediment quality in an ecologically-friendly manner $[5,6]$. This is because the particle-water interaction of suspended particles often represents an important and natural self-cleaning mechanism that scavenges pollutants from natural waters [7]. In return, the improvement in sediment environment and water quality paves the way for ecological and biodiversity restoration.

Over the last few decades, we have developed a series of modified local soil (MLS) materials which can be used to remove HABs and remediate polluted sediment [8]. The multidisciplinary and multifunctional principle of MLS technology is schematically illustrated in Figure 1. The MLS materials are made from clean local soil, or commercially available clay/solid particles [9-11], that are modified by a very small amount of natural products (usually less than $1 \%$ of the soil), such as chitosan [12,13], cationic starch [14], Moringa oleifera [15], and xanthan [16]. The solids can be local soils [12,13], local sands [9], clays [8], red soil, [17] or coal fly ash [10]. MLS is also used for capping and locking the algae flocs or nutrients in the sediment, so that the nutrient release from sediment to water can be reduced [18]. After the MLS flocculation and capping treatment, the decomposition of algae toxins remarkably increases in the sediment compared to bulk water treatment [19]. Subsequently, when the water clarity is achieved, the capped algal flocs and associated nutrients can be utilised in-situ as fertilisers for the growth of submerged macrophytes in shallow water systems [20,21], which is beneficial as macrophytes can support a healthier food chain than algal blooms. Therefore, MLS technology has made it possible to put algae along with the excessive nutrients into the food chain by flocculating and removing them from water into sediment, and converting them into submerged vegetation $[20,21]$. Recently, we have developed an interface oxygen nanobubble technology [22,23], which allows the loading of a substantial amount of oxygen into the microporous surfaces of clays. These clays can stably hold the nanobubbles for months, so that once the oxygen is delivered by settling the clay particles onto the sediment, an aerobic capping layer is formed on top of the anaerobic sediment. This oxidized capping layer can prevent the consumption of dissolved oxygen in the water column by the anaerobic substances from the sediment underneath the capping layer [24,25]. Furthermore, it has been demonstrated that emissions of the greenhouse gases $\mathrm{CH}_{4}$ and $\mathrm{CO}_{2}$ from eutrophic waters can be substantially reduced through the oxygen nanobubble-MLS treatment [26]. Thus, the oxygen nanobubble-MLS treatment may provide a principle for delivering oxygen down into deep waters or sediment without the need for mixing energy (e.g., pumps) to combat anoxia/hypoxia problems that are crucial for eutrophication control [27]. 


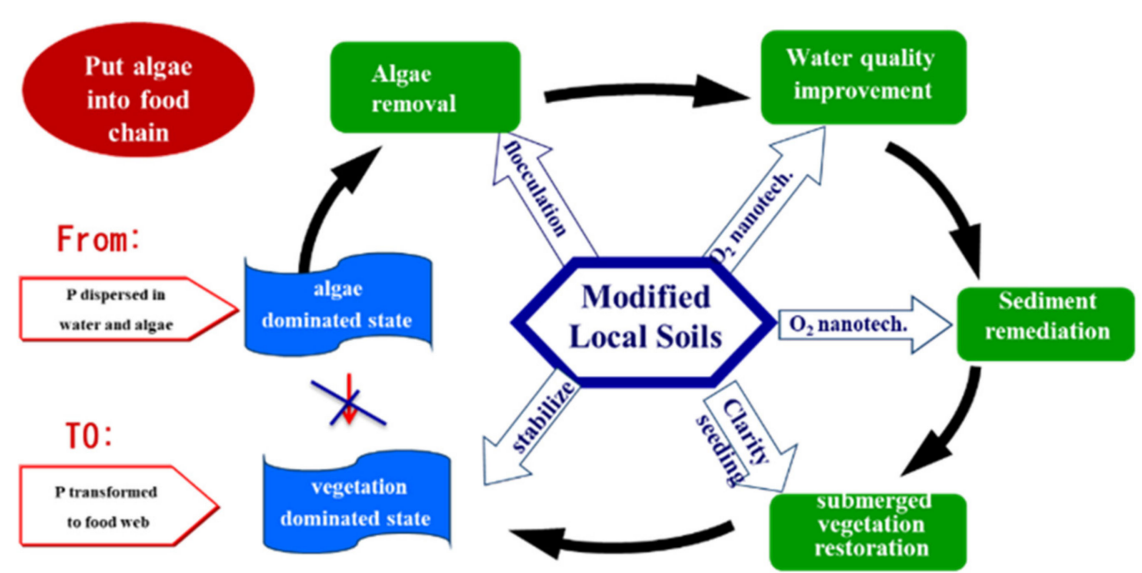

Figure 1. Multi-disciplinary principle of Modified Local Soil (MLS) technology.

The objective of this study is to examine the short-term and mid/long-term effects of MLS technology through a series of pilot whole-pond field experiments in the watersheds of South and North China, respectively. We anticipate that the replicated short term and long term mornitoring results of MLS engineering will provide further insights, and serve as a showcase for local governments, engineers, and researchers who require support for sustainable lake restoration strategies.

\section{Materials and Methods}

\subsection{Materials}

The soils/clays used in the field experiments were collected from the local banks of Lake Tai (South China) and the Cetian Reservoir (North China), respectively. Local soils were washed and screened with a self-designed flotation facility to remove floating substances, and to select suitable particle size fractions $(\sim 70 \mu \mathrm{m})$ of the soil [20]. Chitosan (solid) was obtained from Qingdao Haisheng Bioengineering Co., Ltd (deacetylation degree was 83.6\%). Polyaluminum chloride (PAC) was supplied by Dagang Reagent Plant, Tianjin, China. The basicity $(\mathrm{B}=[\mathrm{OH}] /[\mathrm{Al}])$ of $\mathrm{PAC}$ was 2.4 and its $\mathrm{Al}_{2} \mathrm{O}_{3}$ content was $30 \%$.

\subsection{Experimental Sites}

The whole-pond experiments were conducted in two specifically constructed field experimental sites: 1) Lake Tai, Wuxi city, South China; and 2) Cetian Reservoir, Datong city, North China. Lake Tai is the third-largest freshwater lake in China, which has been suffering from annual harmful algal blooms (HABs) for the last several decades. Five enclosures with a total area of $5000 \mathrm{~m}^{2}\left(4 \times 400 \mathrm{~m}^{2}\right.$, $1 \times 3400 \mathrm{~m}^{2}$ ) were constructed in 2012 in Tanxi Bay for the proposed research (Figure 2). A further three open-water areas in Lake Tai, i.e. Meiliang Bay, Mashan Bay, and Shibai Bay, were also selected for field-scale studies. The Cetian research site consists of eight equally sized water ponds $\left(800 \mathrm{~m}^{2}\right.$ each, with a maximum depth of $1.7 \mathrm{~m}), 12$ large mesocosm systems ( $\Phi 2.5 \mathrm{~m}$ each with a height of $2.5 \mathrm{~m}$ ), and an on-site indoor laboratory equipped with analytical instruments and monitoring facilities (Figure 3). The replicable ponds allowed for the monitoring of environmental responses at an ecologically meaningful scale for the study of Modified Local Soil (MLS) treatments. The two different field sites were chosen because the dominant phytoplankton and ecological status vary under different geological and climate conditions. 


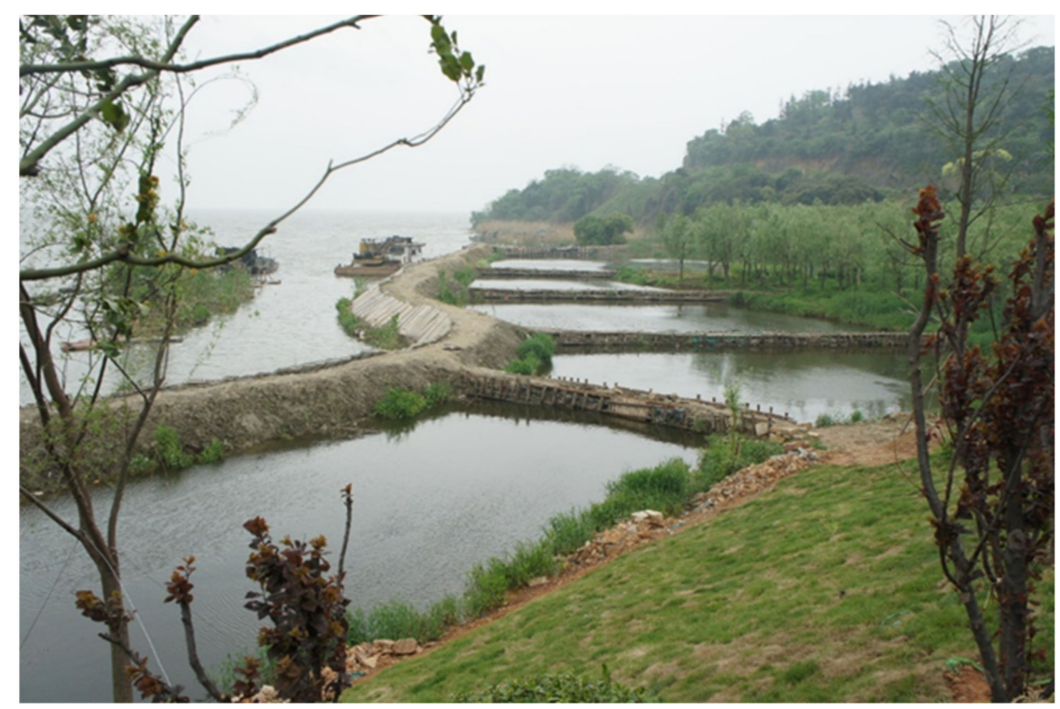

Figure 2. Experimental site in Tanxi bay of Lake Tai.

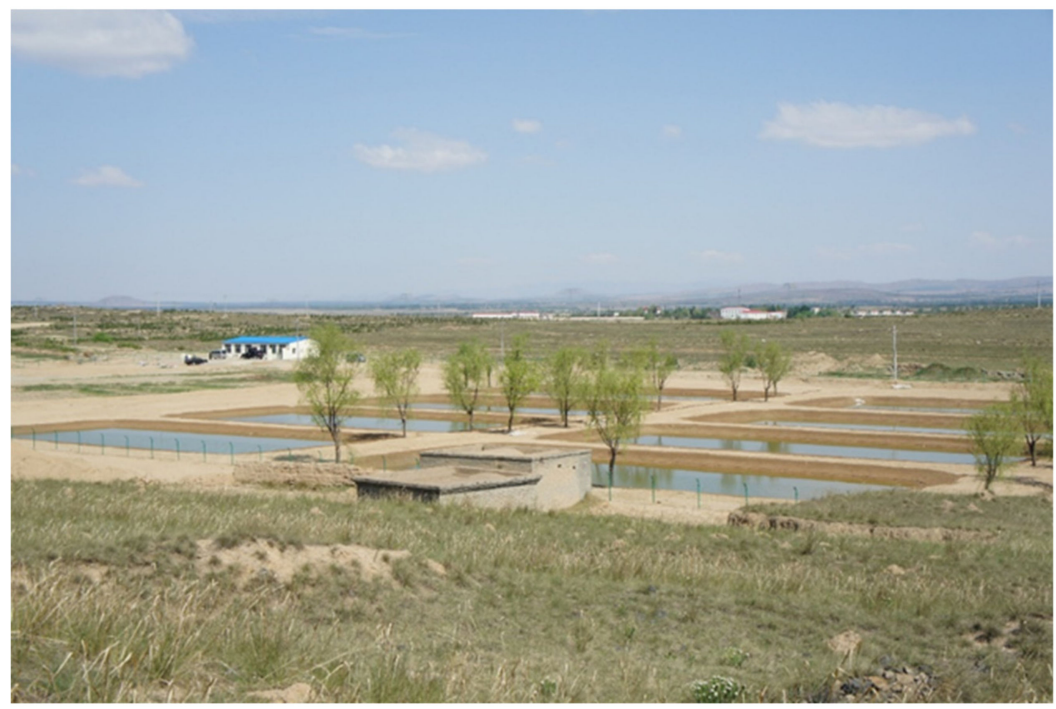

Figure 3. Experimental site in Cetian Reservoir.

\subsection{Preparation of Modified Local Soil}

After a jar test with in-situ water samples, chitosan alone and chitosan-PAC were selected to modify the soil for the experiment held in Lake Tai and Cetian Reservoir, respectively. For the chitosan-MLS preparation, the required amount of chitosan flakes were dissolved in $0.5 \%$ HAc and stirred until all the chitosan was dissolved. This solution was diluted with in-situ pond water to obtain a final concentration of $1 \mathrm{~g} / \mathrm{L}$ before use. The required volume of chitosan solution was then added to the soil suspension (diluted using pond water) to make up a final concentration of $100 \mathrm{mg}$ soil/L and $3 \mathrm{mg}$ chitosan/L in the pond [12,13]. For the Cetian Reservoir pond experiment, chitosan-PAC MLS was used by adding dissolved PAC to chitosan-MLS to achieve a final concentration of $100 \mathrm{mg}$ soil/L, $10 \mathrm{mg}$ PAC/L, and $5 \mathrm{mg}$ chitosan/L in the pond [9].

\subsection{Treatment and Sample Analysis}

This paper summarises five engineering projects conducted by us in Lake Tai (South China) and Cetian reservoir (North China), where MLS technology was used for HABs removal, sediment remediation, and ecology restoration (Table 1). A custom-made spraying facility was used to spray the suspension of 
MLS materials on the surface of the water ponds. After the treatment, water and/or sediment samples were collected from each experiment site to evaluate: 1) Water quality, 2) sediment, and 3) ecology response. Following the flocculation, a $1.5 \mathrm{~cm}$ thick capping was applied in the Lake Tai experiment (projects 3 and 4) using local soil. For the Cetian experiment (project 5), a $1 \mathrm{~cm}$ capping was applied using oxygen nanobubble-modified zeolite, which was prepared following the method described by Zhang, et al. (2018) [24]. Briefly, zeolite was placed in a pressure-resistant, airtight container to create a vacuum $(-0.08$ to $-0.1 \mathrm{MPa}$ for $2 \mathrm{~h}$ ), followed by oxygen nanobubble loading ( 0.12 to $0.15 \mathrm{MPa}$ for $4 \mathrm{~h}$ ), which was repeated three times to achieve super-saturation of $\mathrm{O}_{2}$ in the zeolite micropores.

Table 1. The five engineering projects.

\begin{tabular}{cccccc}
\hline Project & Time & Site & MLS Material & Monitoring & Duration \\
\hline 1 & 2008 & Lake Tai- Meiliang Bay & chitosan MLS & Water (visually) & 1 day \\
2 & 2009 & Lake Tai- Mashan Bay & chitosan MLS & Water (visually) & 1 day \\
3 & 2012 & Lake Tai- Tanxi Bay & chitosan MLS & Water & 20 days \\
4 & 2010 & Lake Tai- Shiba Bay & chitosan MLS & Sediment & 1 year \\
5 & 2012 & Cetian Reservoir & chitosan-PAC MLS & Water & 70 days \\
& & & Ecology & 3 years \\
\hline
\end{tabular}

Water samples were collected to analyse chlorophyll- $a$, turbidity, dissolved oxygen (DO), chemical oxygen demand (COD), transparency, and concentrations of nutrients $\left(\mathrm{TP}, \mathrm{TN}, \mathrm{NH}_{4}^{+}-\mathrm{N}, \mathrm{NO}_{3}^{-}-\mathrm{N}\right.$, and $\mathrm{NO}_{2}^{-}-\mathrm{N}$ ) at different time intervals. Turbidity was analysed with a portable turbidity meter (HANNA, HI98713). The DO was measured using Yellow Springs Instruments (YSI, Proplus). The transparency was detected by a Secchi Disc. COD was determined through Hach test kits with a UV-vis Spectrophotometer (DR 5000, Hach, USA). TP was determined using the potassium persulfate digestion-Mo-Sb-Vc colorimetric method; TN using an alkaline potassium persulfate digestion-ultraviolet spectrometer; $\mathrm{NH}_{4}^{+}-\mathrm{N}$ with Nessler's colorimetric; and $\mathrm{NO}_{3}^{-}-\mathrm{N}$ and $\mathrm{NO}_{2}^{-}-\mathrm{N}$ using the ultraviolet colorimetric method with and without cadmium column reduction, respectively [28]. Chlorophyll- $a(\mathrm{Chl}-a)$ was determined fluorometrically after filtering $1 \mathrm{~L}$ samples through Whatman GF/C filters and extracting the chlorophyll into cold methylated spirit (99\% IMS: 95\% ethanol, $4 \%$ methanol). The concentration of Chl- $a$ was calibrated against direct microscope cell counts to monitor the concentration change of algae cells. Sediment samples were collected using plexiglass cylinders with an inner diameter of $8.4 \mathrm{~cm}$ and height of $50 \mathrm{~cm}$. The concentration of $\mathrm{PO}_{4}^{3-}-\mathrm{P}$ in the pore water of the sediment was determined using Peepers. The device was deployed for 2 days in the sediments for equilibration, to sample pore waters at a vertical resolution of $2 \mathrm{~mm}$. The submerged vegetation samples were randomly collected from a $1 \mathrm{~m}^{2}$ area of each pond. The fresh biomass of different plant species was measured using a weighing balance. Additionally, phytoplankton samples were fixed with Lugol's iodine solution (1.5\% final conc.) and settled for 24 hours. Cell density was measured with a Sedgwich-Rafter counting chamber under a microscopic magnification of $x 400$, and the phytoplankton species were identified according to Hu and Wei (2006) [29].

\section{Results}

\subsection{Water Quality Improvement and Algal Bloom Control}

\subsubsection{Emergent HABs Removal}

An engineering application was conducted under the witness of the Mayor and an expert panel of Wuxi City to clean up heavy algal blooms at two different areas of Lake Tai in 2008 (Figure 4a) and 2009 (Figure 4b), respectively. Chitosan-MLS (approximately $2000 \mathrm{~kg}$ ) was sprayed for 30 minutes using a first generation MLS spraying boat over an enclosure of 50,000 $\mathrm{m}^{2}$ in Meiliang Bay, Lake Tai in August 2008 (project 1 in Table 1). In 2009, a purpose-built automatic second generation MLS spraying boat was manufactured and used in open waters at Mashan Bay, Lake Tai for an emergency treatment of HABs 
on the request of the local government in preparing for an important local event (project 2 in Table 1). Visually, the HABs were rapidly eliminated, and the water clarity increased after a few hours of the MLS treatment.

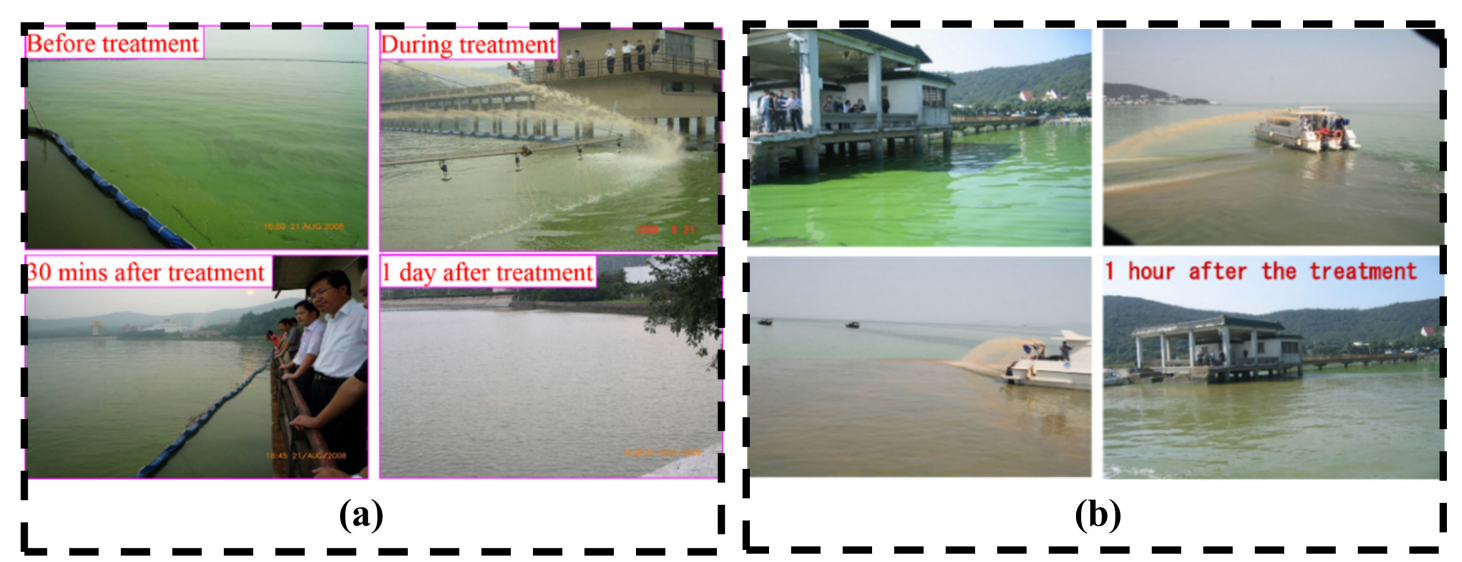

Figure 4. Application of MLS in (a) an enclosure with total area of 50,000 $\mathrm{m}^{2}$ in Meiliang Bay in August 2008, and (b) in open water at Mashan Bay of Lake Tai in August 2009.

\subsubsection{Short-Term Water Quality Improvement}

In 2012, a controlled pilot field experiment was conducted in the water pond at the Tanxi bay (Figure 5) of Lake Tai (project 3 in Table 1). Approximately $16 \mathrm{~kg}$ of chitosan-MLS was sprayed into the water pond $\left(400 \mathrm{~m}^{2}, 1.5 \mathrm{~m}\right.$ depth). The Secchi depth of the pond water was less than $5 \mathrm{~cm}$ before the treatment. After the chitosan-MLS treatment, the algal blooms were removed from the pond within 2 hours, and the transparency of the pond water monitored by a Secchi Disc reached $1.5 \mathrm{~m}$ on the second day post treatment (Figure 5a).

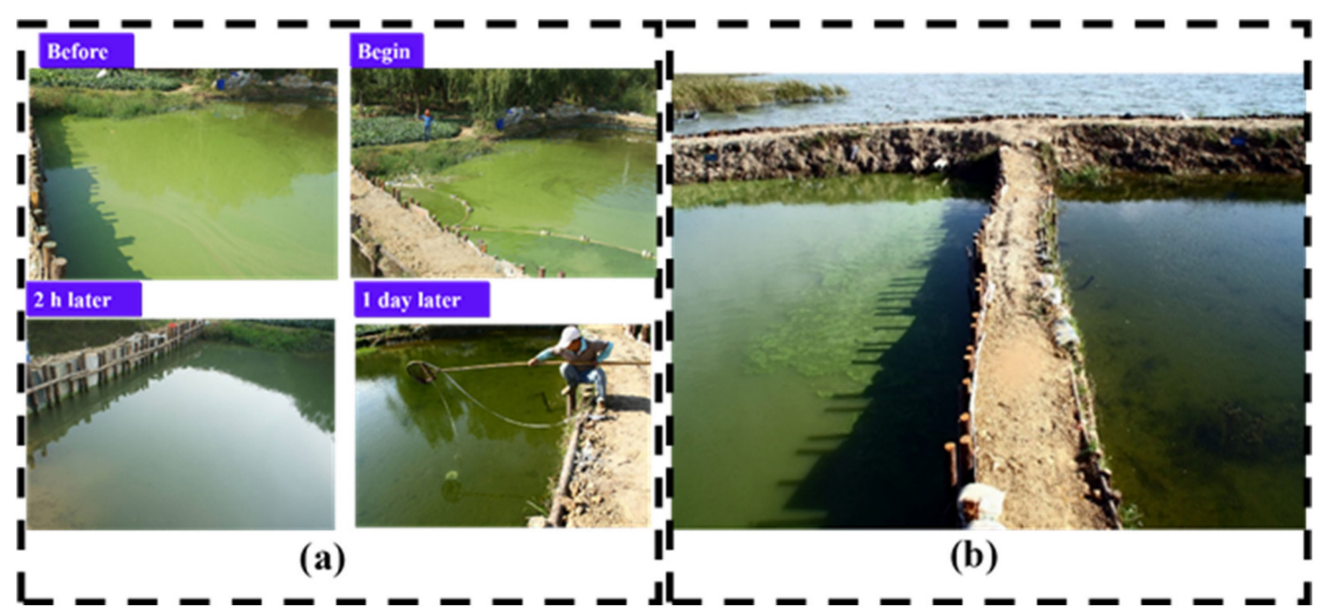

Figure 5. Application of MLS treatment at the Tanxi Bay research site. (a) Visual change of the treatment pond in 1 day; and (b) control (left) and treatment (right) ponds after 20 days.

The short-term changes in water quality were monitored and compared between the treatment and control ponds (Figure $5 b$ ) for a period of 20 days. The Chl- $a$ concentration in the treatment pond decreased from $85 \mu \mathrm{g} / \mathrm{L}$ to $13 \mu \mathrm{g} / \mathrm{L}$, and was maintained below this level for 20 days after the treatment, while the Chl- $a$ concentration in the control pond continually increased, reaching a concentration of $350 \mu \mathrm{g} / \mathrm{L}$ on day 20 (Figure 6). The turbidity was reduced from 95 NUT to 5.3 NUT in the treatment pond, while it was maintained above 100 NUT in the control pond during the same period (Figure 6). The COD and nutrient concentrations, including $\mathrm{TN}, \mathrm{TP}, \mathrm{NO}_{3}^{-}-\mathrm{N}, \mathrm{NO}_{2}^{-}-\mathrm{N}$, and $\mathrm{PO}_{4}^{3-}-\mathrm{P}$, reduced significantly in the treatment pond compared to the control pond (Figure 7). The significant increase of 
Chl-a and TN concentrations at day 20 may be due to the fast growth of the algae in the control pond, which was shown to be largely removed in the treatment ponds.
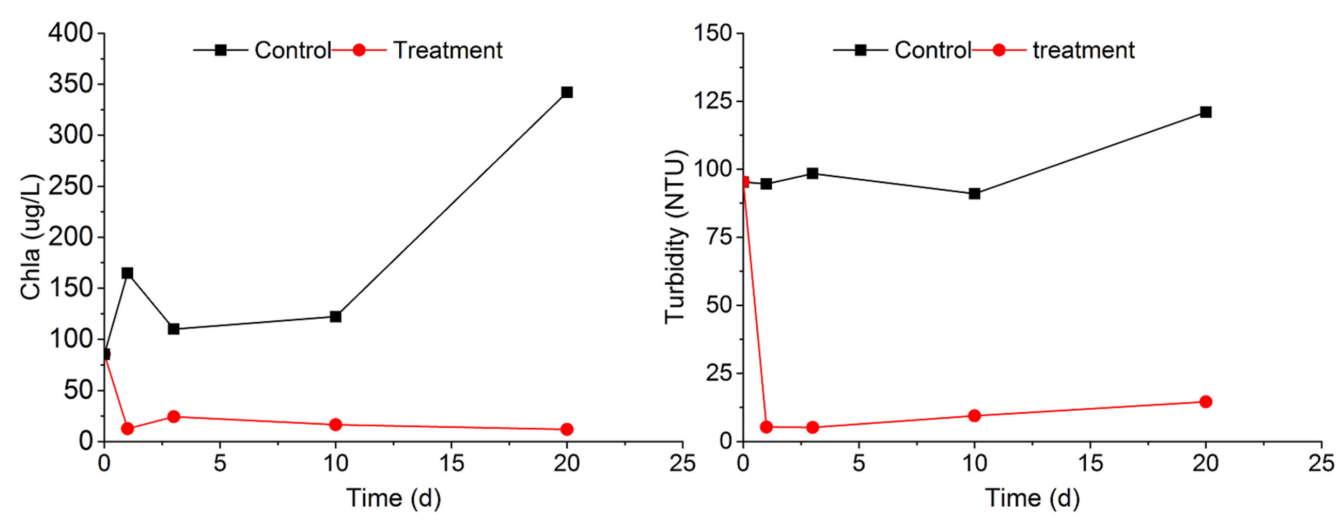

Figure 6. Chl- $\alpha$ concentration and Turbidity changes in the control and treatment ponds.

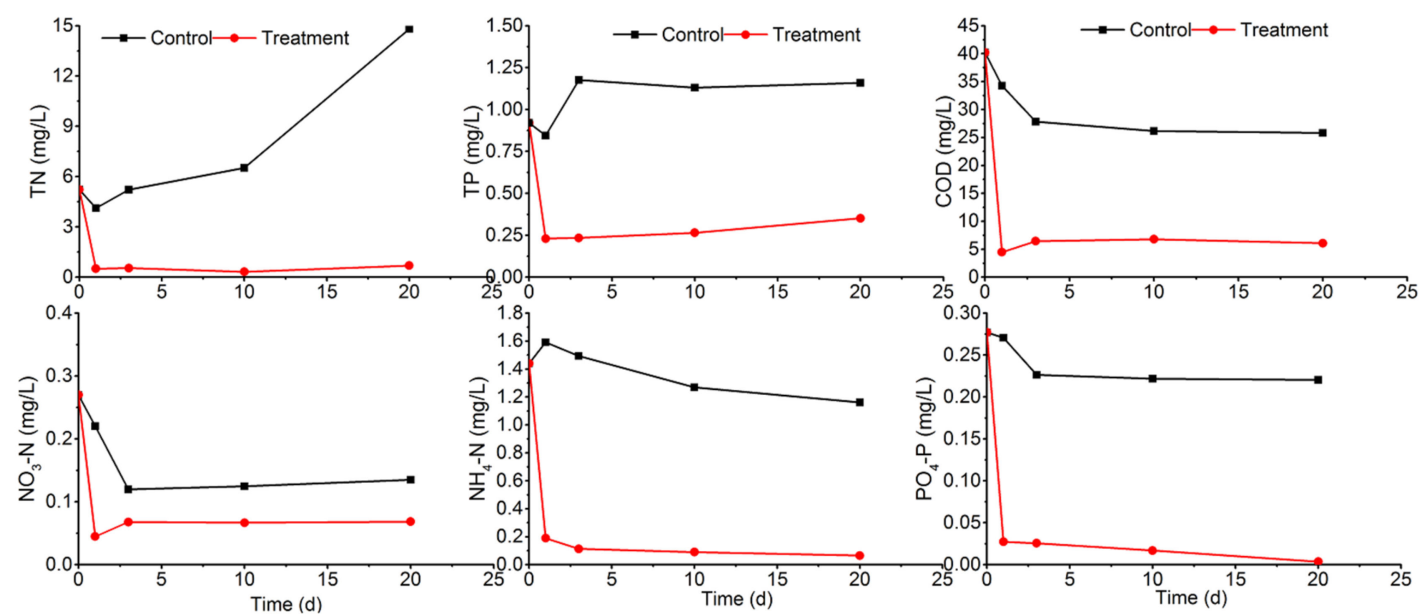

Figure 7. The concentrations of $\mathrm{TN}, \mathrm{TP}, \mathrm{COD}, \mathrm{NO}_{3}^{-}-\mathrm{N}, \mathrm{NO}_{2}^{-}-\mathrm{N}$, and $\mathrm{PO}_{4}^{3-}-\mathrm{P}$ in control and treatment ponds.

\subsubsection{Mid-Term Water Quality Improvement}

A mid-term whole-pond experiment was conducted in the Cetian Reservoir research site in July 2012 (Figure 8, project 5 in Table 1). Approximately $32 \mathrm{~kg}$ of chitosan-PAC MLS was sprayed into the treatment pond $\left(800 \mathrm{~m}^{2}, 1.5 \mathrm{~m}\right.$ depth). The water quality parameters in the treated and control ponds after 70 days are presented in Table 2. The water quality in the control ponds remained as a grade bad-V (a Chinese natural water quality standard) during the 70 days monitoring period. In the treatment ponds, the $\mathrm{TN}, \mathrm{TP}, \mathrm{NH}_{4}^{+}-\mathrm{N}$, and COD concentrations improved to a grade III (Table 2).

Table 2. The mid-term effect of MLS treatments on water quality after 70 days in the control and treatment ponds.

\begin{tabular}{ccccccc}
\hline & $\mathbf{p H}$ & $\mathbf{D O}$ & $\mathbf{T N}$ & $\mathbf{T P}$ & $\mathbf{C O D}$ & $\mathbf{N H}_{\mathbf{4}}{ }^{+}-\mathbf{N}$ \\
\cline { 3 - 7 } & & & \multicolumn{5}{c}{$\mathbf{m g} / \mathrm{L}$} \\
\hline Treated Pond & 9 & $10.8^{\mathrm{I}}$ & $0.8^{\mathrm{II}}$ & $0.08^{\mathrm{II}}$ & $14.5^{\mathrm{II}}$ & $0.4^{\mathrm{II}}$ \\
Std. & 0.4 & 1.4 & 0.3 & 0.03 & 2.1 & 0.2 \\
Control Pond & 8.9 & $5.9^{\mathrm{II}}$ & $3.1^{\mathrm{b}^{\mathrm{V}}}$ & $0.5^{\mathrm{b}^{\mathrm{V}}}$ & $58^{\mathrm{b}^{\mathrm{V}}}$ & $1.1^{\mathrm{IV}}$ \\
Std. & 0.5 & 0.9 & 1.8 & 0.3 & 8.5 & 0.3 \\
\hline
\end{tabular}

Note: I, II, III, IV and $\mathrm{b}^{\mathrm{V}}$ represent the water quality grades based on environmental quality standards for surface water of China. 


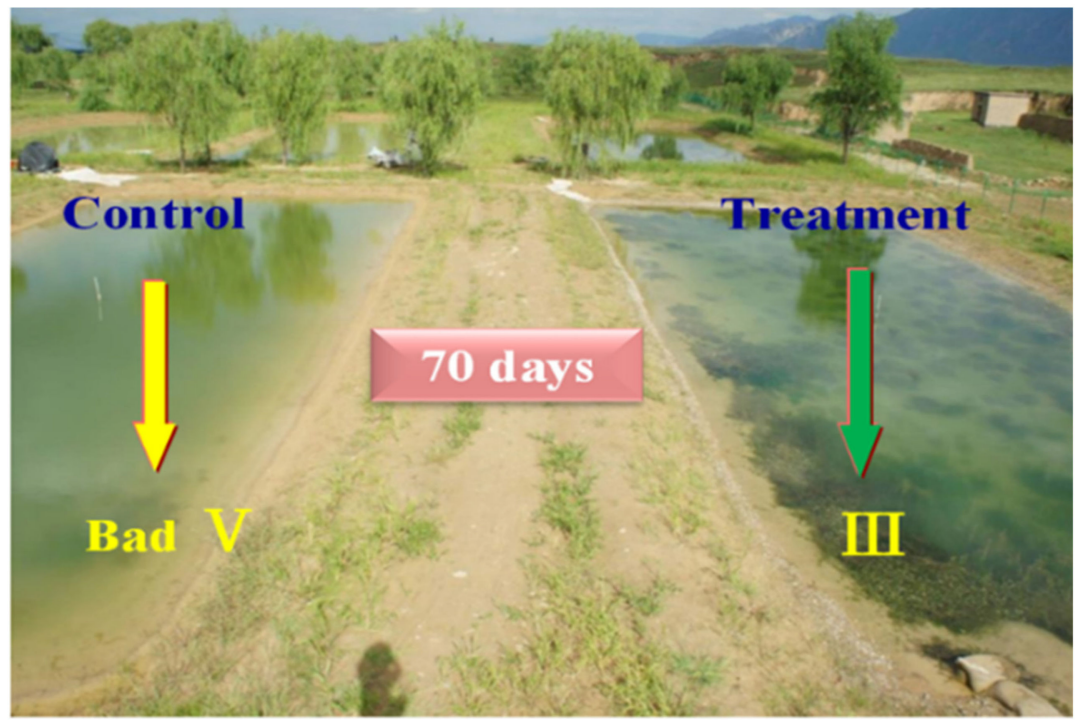

Figure 8. Control (left) and treatment (right) ponds at Cetian Reservoir.

\subsection{Sediment Remediation}

A one year monitoring experiment was conducted in open water at Shiba Bay of Lake Tai in 2010 (project 4 in Table 1). The chitosan-MLS capping material was applied to a $4 \mathrm{~m}^{2}$ sediment in the open lake, so that the overlying water condition remained the same as the surrounding untreated algae water, but the $4 \mathrm{~m}^{2}$ sediment differed from the surounding sediment throughout the year. After the MLS capping treatment, a $1.5 \mathrm{~cm}$ capping layer was formed (Figure 9). Sediment-water fluxes of nutrients in the capping area were monitored and compared with the surrounding untreated sediment. During summer and autumn, $\mathrm{PO}_{4}^{3-}-\mathrm{P}$ flux across the sediment-water interface was largely reduced in the treated area $\left(4 \mathrm{~m}^{2}\right)$ compared to the untreated surrounding area (Figure 10).
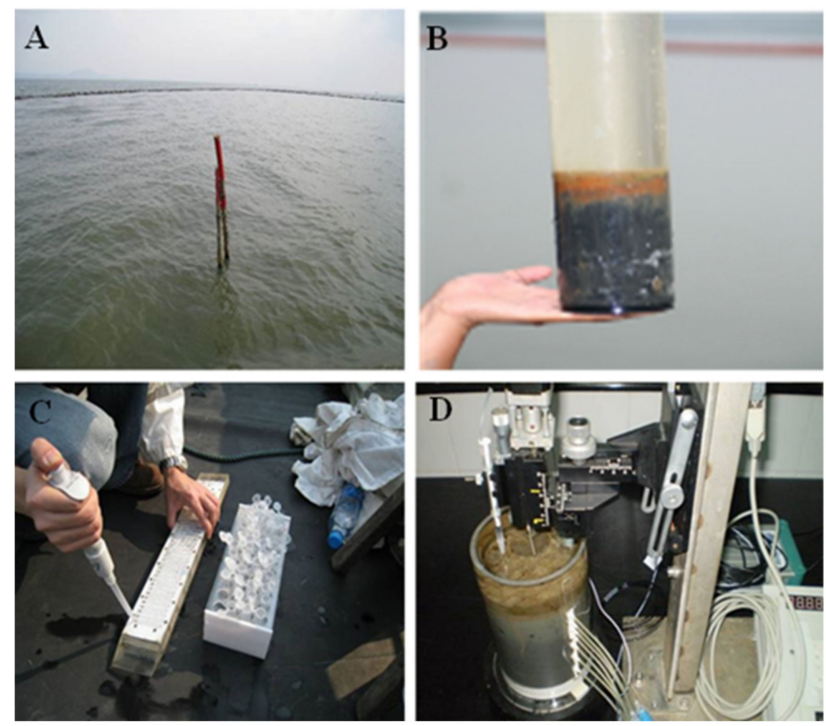

Figure 9. Sediment sampling in the open water in Shiba Bay of Lake Tai after the MLS treatment. 

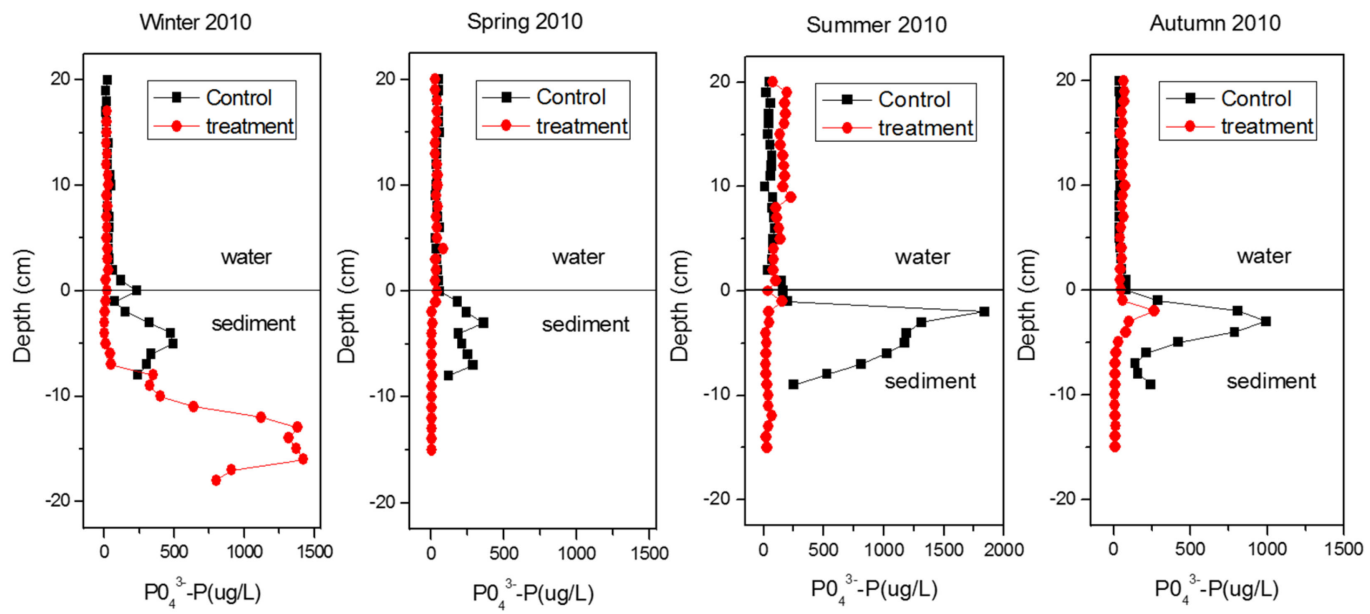

Figure 10. Changes of $\mathrm{PO}_{4}^{3-}-\mathrm{P}$ profile throughout the year at the treated sediment area (red) and untreated sediment (black).

\subsection{Long Term Ecological Restoration}

The ecological responses of the MLS treatment was monitored at the Cetian research site (Figure 11, project 5 in Table 1). Compared to the control pond, the submerged vegetation had been successfully restored in the treatment ponds. After four months, following the chitosan-PAC MLS treatment, the total biomass of submerged vegetation increased from 150 to $1031 \mathrm{~g} / \mathrm{m}^{2}$ and the aquatic vegetation coverage rate exceeded $65 \%$ (Figure 12a). Whereas in the control pond, the total biomass of submerged vegetation was $75 \mathrm{~g} / \mathrm{m}^{2}$ and the aquatic vegetation coverage rate was less than $10 \%$. The pond was successfully transformed from an algae-dominated state to a vegetation-dominated state. In order to maintain the balance of the aquatic ecological system, the submerged vegetation was harvested once annually by mechanical machines in the $2^{\text {nd }}$ year and $3^{\text {rd }}$ year, which helped to remove nutrients from the water, and maintain the ecological balance and water clarity. The dominant species of macrophytes in the treatment pond were P. malaianus, P. pectinatus and P. crispus (Figure 12b).

The composition and cell count of the phytoplankton in the control and treatment ponds after the MLS treatment are shown in Figure 13. Chlorophytes were the dominant phytoplankton in all the ponds before the treatment, which was kept the same in the control ponds from June to October. One month after the MLS treatment, about $75 \%$ of the algal cells were removed from the water column, and the percentage of the dominant Chlorophytes was reduced from $72 \%$ to $48 \%$. During July and August, Cyanophytes became the dominant species, and Chlorophytes, along with Bacillariophytes, remained as the sub-dominant phytoplankton. During September and October, the percentage of Bacillariophytes increased due to the decreasing water temperature. Hence, throughout the monitoring period, the phytoplankton biodiversity increased, and the total algal cells decreased in the treatment pond. 

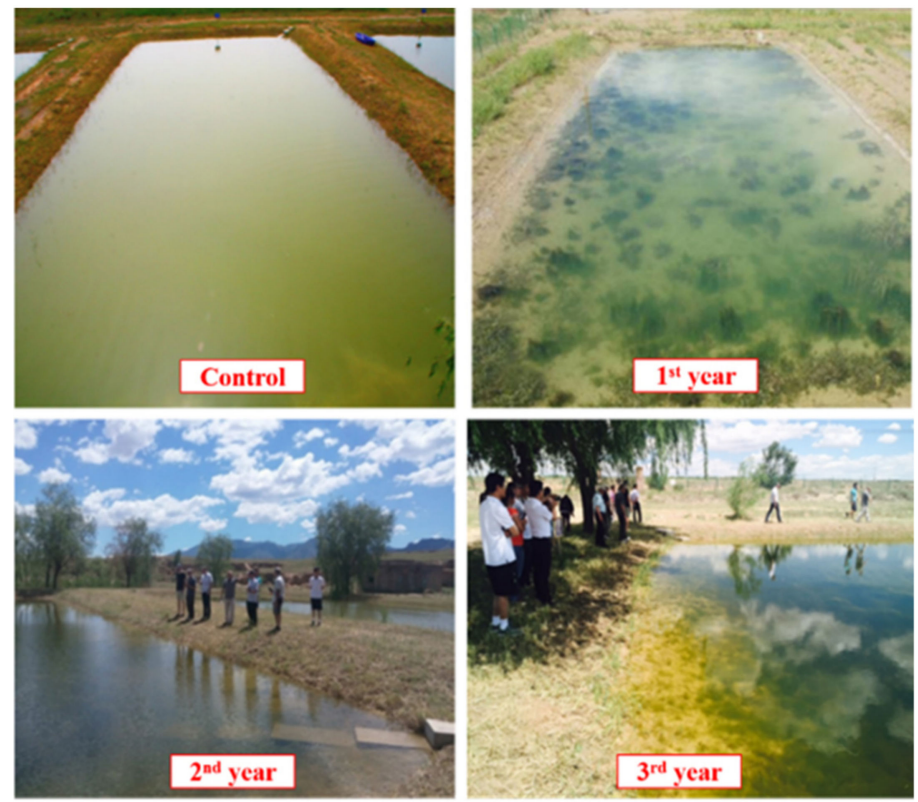

Figure 11. Ecological responses monitoring experiment at Cetian research site after MLS treatment.

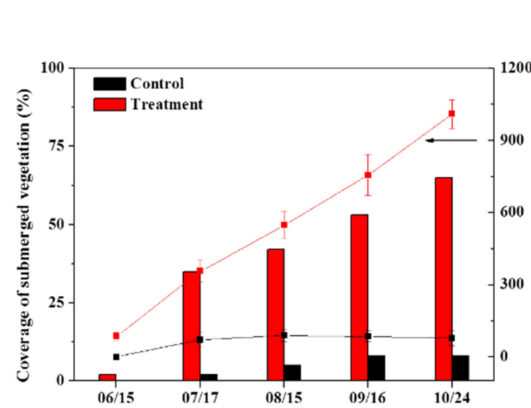

(a)

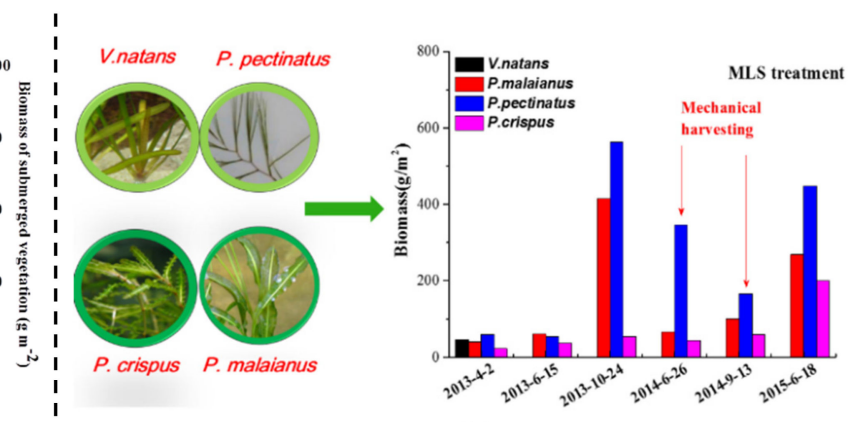

(b)

Figure 12. (a) The coverage and biomass of submerged vegetation in the control and treatment ponds after 4 months and (b) a 3-year monitoring result on submerged vegetation restoration in the treated pond.

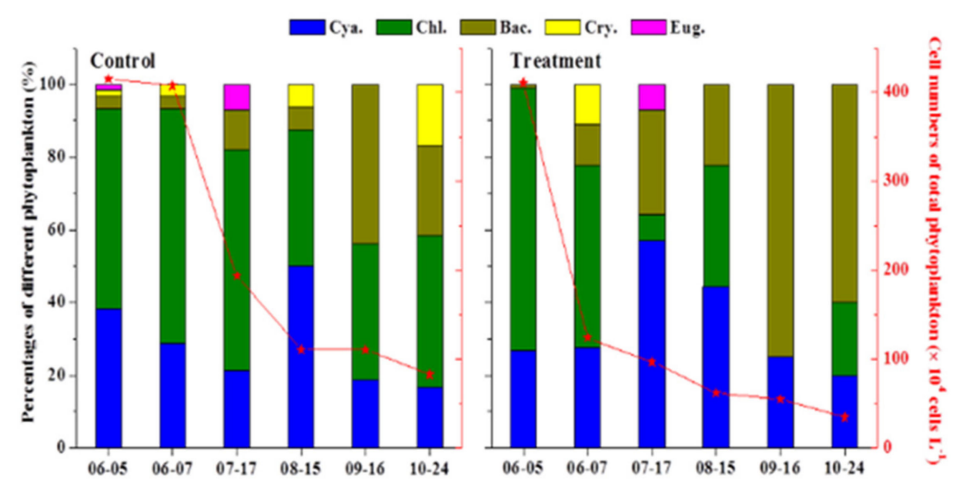

Figure 13. Changes of the dominant phytoplankton composition in the control and treatment ponds.

\section{Disscussion}

\subsection{Water Quality}

The principles used in MLS technology (Figure 1) for water quality improvement is flocculation for particulate pollutants (e.g., algae cells) and adsorption for dissolved pollutants. Suspended particles are ubiquitous in natural waters [7]; they play important roles in expelling pollutants through the 
aforementioned principles, i.e. particle-particle interactions (flocculation) or particle-water interactions (adsorption). We have found that many natural products, such as chitosan [12,13], cationic starch [14], Moringa oleifera extracts [15,30], and xanthan [16], can greatly enhance these interactions, and thus be used to modify solid particles for algae flocculation. These solid particles are important for increasing the number of collisions between particles and algae cells for flocculation, as well as providing a ballast for settling. MLS is an effective way to retain high concentrations of flocculants on solid surfaces whilst maintaining a relatively low concentration in solution. This can increase the effective collisions between particles so as to avoid a high concentration of flocculants needed in water. The solids used can be local soils [12,13], clay [8], sands [9], industrial by-products [10], and other cheap and safe solids [31]. The effect of flocculation is often affected by the type of algae and water composition (e.g., salinity levels $[13,15])$. Therefore, a jar test is always nessasary before any engineering work commences, in order to decide the optimized dosage and composition of the MLS materials. Understanding the flocculation mechanism is also important for finding the appropriate recipes. The formation of small floppy flocs using inorganic flocculants is often not enough to achieve an obvious engineering effect in the field due to natural disturbances (e.g., wind and current). The polymer modifiers with net and bridging properties are important to form large flocs, which can either sink the flocs to the bottom using clay/soil ballasts, or harvest the flocs via floating bubbles [1]. In Lake Tai, the dominant blue-green algae is the cyanobacteria such as Microcystis aeruginosa, which often exists in a colonised form. Chitosan-MLS using local soil is very effective in cleaning up colonised Microcystis aeruginosa in fresh waters (projects 1-3). In the Cetian reservoir (project 5), Chlorophytes were the dominant phytoplankton. For blooms in high salinity waters, a chitosan and PAC combined modification of local soil is needed for a more effective clean-up.

It is well documented that nutrient limitation is important for the management of eutrophication [2]. Using the same pond at the Tanxi research site (project 3 in Table 1), we found that nutrient limitation can be manipulated using MLS treatment. The nutrient limitation in the whole-pond experiment was shifted from nitrogen $(\mathrm{N})$ and phosphorus $(\mathrm{P})$ co-limitation to $\mathrm{P}$ limitation within six months after MLS treatment compared to the control pond [32].

\subsection{Sediment Remediation}

\subsubsection{Shallow Waters}

Internal sediment nutrient release is one of the main reasons for eutrophication in shallow lakes. When algae biomass flocculates from the water to the sediment, it reduces the immediate harmful effect of the HABs in water, but increases the sediment loading, which holds a high risk of returning the algae back to the water column via resuspension or diffusion. An MLS capping layer can not only prevent the resuspension of the algal flocs, but also reduce the nutrient release into the overlying water from the sediment [18]. Microorganism-modified MLS is also effective in decomposing algae toxins, because MLS flocculation will result in the intense accumulation of microbes and algae cells under the capping layer, as compared to that in the bulk water [19]. For shallow water sediment, the MLS capping aims to provide a 'window period' (usually for a few months in shallow waters) to reach appropriate water and sediment quality levels for the restoration of submerged vegetation [21].

\subsubsection{Deep Waters}

The flux of nutrients from sediment to water is very sensitive to redox reactions. Many elements such as $\mathrm{P}, \mathrm{N}, \mathrm{C}, \mathrm{S}$, and other metal ions tend to be released from sediment to water under anoxic conditions. Current remediation strategies for deep water hypoxia are mainly based on the delivery of oxygen using artificial energy (e.g., pumping). For deep large water bodies, the use of mixing energy (e.g., ventilation of surface water down to deep water) can be very laborious, expensive, and carry a risk of triggering the resuspension of anaerobic substances and a change of water stratification. The interfacial oxygen nanobubble technology can cheaply and safely deliver oxygen to deep water 
sediment due to the clay gravity, without the need for these mixing energies [24]. The oxygen-locking layer between the overlying water and sediment could play important roles in both the physical isolation and chemical fixation of pollutants in the sediment. The oxygen-locking layer could affect many geochemical and microbial processes, thereby opening a new possibility to remediate sediment, especially for deep waters, which are usually very difficult. For instance, oxygen nanobubble-MLS can be used to remediate the sediment to reduce methane emissions [26]. Another effective way to lock phosphorus in the sediment is to use Phoslock, which has so far been tested in about 200 water bodies worldwide [31]. We have recently developed new geo-engineering materials, which have a P removal capacity 5 to 8 times higher than the commercially available Phoslocks [33,34]. The principle of MLS for sediment remediation (Figure 1) is to use natural geo-engineering materials to reduce the resuspension of the sediment, to adsorb and lock phosphorus, and alter redox conditions at sediment-water interfaces to control the internal loads. We believe the oxygen nanobubbles-MLS will attract particular attention in the future, due to its great potential for deep-water sediment remediation, which is a serious and challenging issue worldwide.

\subsection{Ecological Restoration}

It is well recognised that TP reduction is one of the key factors in controlling the alternation between an algae-dominated state and a vegetation-dominated state [35]. The restoration of submerged macrophytes in polluted water can be very slow under poor water and sediment conditions. MLS can be used to decrease the TP quickly so as to accelerate the ecological restoration on a large engineering scale. Once a stabilised and optimised vegetation state is established in shallow waters, it will help to maintain the water quality on a long-term basis. Nutrients are needed for the growth of submerged vegetation, but high TP levels will only lead to the degradation of submerged macrophytes, as the algae holds the priority to use the nutrients to become a bloom. MLS flocculation and capping can help redistribute the nutrients in such a way that once nutrients are taken up by the algae cells, they can be flocculated and buried in the sediment. The buried nutrients under the MLS capping layer can be utilised by submerged macrophytes compared to that in water. This was demonstrated in the treatment pond at the Cetian research site (project 5 in Table 1).

The restored macrophytes of P. malaianus, P. pectinatus and P. crispus in project 5 have a strong nutrient assimilation ability. The concentrations of TN and TP in the treatment pond were much lower than those in the control pond, and the TP in the treatment pond remained lower than $0.1 \mathrm{mg} / \mathrm{L}$ (Table 2) during the monitoring period. Meanwhile, the total biomass of the submerged vegetation increased and the cell numbers of phytoplankton decreased continuously (Figures 11 and 12). Submerged vegetation was responsible for the water quality in the mid- and long-term, because they assimilated nutrients and inhibited algae reproduction in the ecosystem. For shallow water engineering, the restored submerged macrophytes triggered by MLS could be regularly harvested and managed, so that the nutrients can be continually removed from the water while sustaining the balance and health of the ecological system and sediment respectively. Once the algae is turned into vegetation, it is then much easier to harvest macrophytes using mechanical management than it would have been to harvest the algal blooms. Additionally, the levels of indigenous macrophyes may be kept naturally balanced by fish through the food chain.

In a previous engineering study, a 100,000 $\mathrm{m}^{2}$ whole bay with heavy algal blooms located in Liangyangyuan Bay in Lake Tai was treated by MLS, and the biodiversity index steadily increased within the six months monitoring period after the treatment [20]. In practice, it is often necessary to selectively control fish, as they can seriously influence the treatment effect of MLS especially at the sediment remediation stage before the vegetation system has established in shallow waters.

\subsection{Cost Analysis}

MLS technology provides several functions, including HABs removal, water quality improvement, sediment remediation, $\mathrm{O}_{2}$ supply, and ecological restoration (Fig. 1). The cost of implementation 
depends on the needed functions of individual engineering project. For HABs flocculation, various particle materials, such as kaolinite and local soil, may be used depending on their local price and availability. Short-term HABs removal using MLS is very cost-effective compared to other existing methods. The price of flocculating apparent HABs in $0.5 \mathrm{~m}$ surface water is between US\$30-60K per $\mathrm{km}^{2}$; the price is mainly affected by the modifier used (Table 3 ). The modification recipe may vary depending on the water quality (e.g., salinity levels) and the dominant algal species. For example, the chitosan-MLS and chitosan-PAC MLS is appropriate for the eutrophic lakes dominated by Microcystis aeruginosa [8] and Chlorophytes in projects 3 and 5 (Table 1), respectively. As the treatment area increases, it is more feasible to make use of local soil rather than commercial clays with respect to effect and cost. Submerged macrophytes are key for long-term maintenance of water clarity in shallow waters, but they can be hardly restored in algae dominated systems. To achieve such long-term effects, capping is often necessary following flocculation, especially in shallow waters. Table 3 shows that capping using clean local soils or sands (US\$ $0.9 \mathrm{M} / \mathrm{km}^{2}$ ) is much cheaper than using commercial clays such as granule zeolite (US\$1.8 M/ $\mathrm{km}^{2}$ ). For deep water systems, the effect of flocculation alone may last much longer than in shallow waters. However, to prevent the reoccurrence of HABs, the sediment nutrient release needs to be fixed, which is where interfacial oxygen nanobubbles may be particularly useful [24]. The cost of oxygen needed in oxygen nanobubble-modified zeolite is much lower than the cost of zeolite itself, which is about US\$ $30 \mathrm{~K} / \mathrm{km}^{2}$ (Table 3). The operational costs (including the boat, fuel, and labour) to mechanically spray the MLS materials is about US $\$ 1.5 \mathrm{~K} / \mathrm{km}^{2}$. To sumarize, for a short-term algal clean-up using MLS and mid-term capping treatment using zeolite, the total cost is about US\$1.9 M/km². The cost heavily depends on the thickness of the capping materials needed, rather than the flocculation of the HABs.

Table 3. Summary of the cost per $\mathrm{km}^{2}$ of field implementation of Modify Local Soil (MLS) technology.

\begin{tabular}{|c|c|c|c|c|c|c|}
\hline \multicolumn{2}{|c|}{ Particle Materials } & \multicolumn{2}{|c|}{ Flocculation by MLS ${ }^{1}$} & \multirow{2}{*}{$\begin{array}{c}\text { Capping }^{4} \\
\text { Price } \\
\left(\mathbf{k} \$ / \mathbf{k m}^{2}\right)\end{array}$} & \multirow{2}{*}{$\begin{array}{c}\text { Extra } \mathrm{O}_{2} \text { Supply }^{5} \\
\mathrm{O}_{2} \text { nanobubble } \\
\text { Modification }\left(\mathrm{k} \$ / \mathrm{km}^{2}\right)\end{array}$} & \multirow{2}{*}{$\begin{array}{c}\text { Operation } \\
\begin{array}{c}\text { Mechanic Spray } \\
\left(\mathbf{k} \$ / \mathrm{km}^{2}\right)\end{array}\end{array}$} \\
\hline Types & $\begin{array}{l}\text { Price } \\
(\$ / t)\end{array}$ & $\begin{array}{l}\text { Chitosan MLS } \\
\left(\mathrm{k} \$ / \mathrm{km}^{2}\right)\end{array}$ & $\begin{array}{l}\text { Chitosan-PAC } \\
\text { MLS }^{3}\left(\mathbf{k} \$ / \mathbf{k m}^{2}\right)\end{array}$ & & & \\
\hline Kaolinite & 135 & 38 & 59 & 2024 & - & 1.5 \\
\hline Local soil & 60 & 35 & 56 & 900 & - & 1.5 \\
\hline zeolite & 120 & - & - & 1799 & 30 & 1.5 \\
\hline
\end{tabular}

Note: ${ }^{1}$ Flocculation of apparent harmful algal blooms (HABs) in $0.5 \mathrm{~m}$ surface water; ${ }^{2}$ Based on Lake Tai projects (project 1-3 in Table 1); ${ }^{3}$ Based on the Cetian Reservoir project (project 5 in Table 1); ${ }^{4}$ Based on $1 \mathrm{~cm}$ depth of capping; ${ }^{5}$ Based on project 5 of $1 \mathrm{~cm}$ capping of $\mathrm{O}_{2}$ nanobubble-modified zeolite.

\subsection{Ecological Safety}

So far, natural clay or soils used as a ballast have not shown any negative side-effect on aquatic ecological systems. Continuous supply of high concentration suspended particles in natural rivers and lakes may cause siltation, but not ecological problems. Rather, suspended particles are important for the transport and transformation of elements in natural waters $[7,36]$. The amount of soil/clay used in MLS treatments is lowcompared to the natural conditions of many rivers (e.g., Yellow River). When clean soil/clay settles on heavily polluted sediment, it often represents an improvement of sediment quality. There have been concerns regarding the use of PAC, a chemical reagent used in drinking water treatment, in natural waters. Existing toxicity studies illustrate that PAC is among the most non-toxic flocculants for aquatic organisms [37,38]. However, the long-term ecological effect for the non-biodegradable compound remains a concern, and requires further studies. When chitosan is not used together with clay/soil, it may have antimicrobial properties against some bacteria [39] including cyanobacteria species [40]. Our recent study found that the combination of chitosan with natural soils could greatly reduce the toxicity to the aquatic organisms exerted by chitosan alone [38]. This is because MLS makes it possible to keep the concentration of chitosan low in the water, while remaning high on soil particles, which is essential to maintain a high flocculation efficiency whilst maintaining a low toxic effect. When capping is used following the flocculation treament, lysis of algae 
cells may take place, which is benefcial in avoiding a re-growth of the algae and the degradation of algae toxins [19]. We have also found that some industrial by-products with a relatively high content of aluminum or iron ions, such as coal fly ash, could also be used to modify soils [10], although their potential environmental risk requires further invsetigation.

For practical lake restoration engineering, conditions are often complex and variable. There are many interfering factors in the field (such as wind and bio-disturbance) and it is very important to study these influences and their counter measures before implementing an artificial geo-engineering treatment.

\section{Conclusions}

The short and mid/long-term effects of MLS treatments were investegated through 5 whole-pond or open-lake scale experiments. Results showed that, combined with an integrated management of external loads control, MLS can be used as an in-lake technology for lake restoration through its multiple functions of water quality improvement (projects 1-3), sediment remediation (project 4), and ecological restoration (project 5). These findings can serve as useful guidelines for researchers, engineers, and local governments for controlling eutrophication and accelaerating lake restoration in an eco-friendly and sustainable manner.

Author Contributions: Conceptualization, G.P.; Funding acquisition, G.P.; Investigation, G.P.; Methodology, L.B., H.Z., Lei Wang, Lijing Wang, Z.W., X.M., J.C., J.A., M.P., J.Z., and B.Y.; Project administration, G.P.; Writing-original draft, G.P., L.B., H.Z., Lei Wang, and T.L.; Writing—review \& editing, G.P., Lijing Wang, B.Y. and T.L.

Acknowledgments: This research was supported by the National Key Research and Development Program of China (2017YFA0207204), the Key R\&D program of MoST (2002AA601011), Chinese National Basic Research Program (2002CB412308; 2008CB418105; 2010CB933600; and the Strategic Priority Research Program of CAS (XDA09030203). We thank Bashaer Shariff for proof reading.

Conflicts of Interest: The authors declare the following competing financial interests: Several authors are co-inventors of patents related to the technology described in this paper for which they are entitled to receive royalties. GP and HZ are co-inventors of Chinese Patent No. 201810350928.0; GP, LW, ZW and LB are co-inventors of Chinese Patent Nos. 201210325832.1 and CN201110190392.9. GP is the first inventor of Chinese Patents Nos. ZL02155284.3; ZL200910080563.5; 201410141698.9; ZL2008100576735; 201210180985.1; ZL200510099736.X; CN201110194044.9; CN201010104197.5; CN201010104186.7; CN2010101041890; CN201010214522.3; CN201010288173.X. GP is the first inventor of U.S. Patent No. US 7,758,752 B2 and Australia Patent No. 2005336317. Above mentioned patents are originally issued to Research Center for Eco-Environmental Sciences, Chinese Academy of Sciences.

\section{References}

1. Pan, G.; Lyu, T.; Mortimer, R. Comment: Closing phosphorus cycle from natural waters: Re-capturing phosphorus through an integrated water-energy-food strategy. J. Environ. Sci. 2018, 375-376. [CrossRef] [PubMed]

2. Conley, D.J.; Paerl, H.W.; Howarth, R.W.; Boesch, D.F.; Seitzinger, S.P.; Havens, K.E.; Lancelot, C.; Likens, G.E. Controlling eutrophication: Nitrogen and phosphorus. Science 2009, 323, 1014-1015. [CrossRef] [PubMed]

3. Khare, Y.; Naja, G.M.; Stainback, G.A.; Martinez, C.J.; Paudel, R.; van Lent, T. A phased assessment of restoration alternatives to achieve phosphorus water quality targets for Lake Okeechobee, Florida, USA. Water 2019, 11, 327. [CrossRef]

4. Lürling, M.; Mackay, E.; Reitzel, K.; Spears, B.M. Editorial-A critical perspective on geo-engineering for eutrophication management in lakes. Water Res. 2016, 97. [CrossRef]

5. Mackay, E.B.; Maberly, S.C.; Pan, G.; Reitzel, K.; Bruere, A.; Corker, N.; Douglas, G.; Egemose, S.; Hamilton, D.; Hatton-Ellis, T. Geoengineering in lakes: Welcome attraction or fatal distraction? Inland Waters 2014, 4, 349-356. [CrossRef]

6. Spears, B.M.; Maberly, S.C.; Pan, G.; Mackay, E.; Bruere, A.; Corker, N.; Douglas, G.; Egemose, S.; Hamilton, D.; Hatton-Ellis, T. Geo-engineering in lakes: A crisis of confidence? Environ. Sci. Technol. 2014. [CrossRef]

7. Pan, G.; Krom, M.D.; Zhang, M.; Zhang, X.; Wang, L.; Dai, L.; Sheng, Y.; Mortimer, R.J. Impact of suspended inorganic particles on phosphorus cycling in the Yellow River (China). Environ. Sci. Technol. 2013, 47, 9685-9692. [CrossRef] 
8. Pan, G.; Zhang, M.-M.; Chen, H.; Zou, H.; Yan, H. Removal of cyanobacterial blooms in Taihu Lake using local soils. I. Equilibrium and kinetic screening on the flocculation of Microcystis aeruginosa using commercially available clays and minerals. Environ. Pollut. 2006, 141, 195-200. [CrossRef]

9. Pan, G.; Chen, J.; Anderson, D.M. Modified local sands for the mitigation of harmful algal blooms. Harmful Algae 2011, 10, 381-387. [CrossRef]

10. Yuan, Y.; Zhang, H.; Pan, G. Flocculation of cyanobacterial cells using coal fly ash modified chitosan. Water Res. 2016, 97, 11-18. [CrossRef]

11. Biswas, B.; Warr, L.N.; Hildera, E.F.; Goswami, N.; Rahman, M.M.; Churchman, J.G.; Vasilev, K.; Pan, G.; Naidub, R. Biocompatible functionalisation of nanoclays for improved environmental remediation. Chem. Soc. Rev. 2019. (under revision).

12. Zou, H.; Pan, G.; Chen, H.; Yuan, X. Removal of cyanobacterial blooms in Taihu Lake using local soils II. Effective removal of Microcystis aeruginosa using local soils and sediments modified by chitosan. Environ. Pollut. 2006, 141, 201-205. [CrossRef]

13. Pan, G.; Zou, H.; Chen, H.; Yuan, X. Removal of harmful cyanobacterial blooms in Taihu Lake using local soils III. Factors affecting the removal efficiency and an in situ field experiment using chitosan-modified local soils. Environ. Pollut. 2006, 141, 206-212. [CrossRef]

14. Shi, W.; Tan, W.; Wang, L.; Pan, G. Removal of Microcystis aeruginosa using cationic starch modified soils. Water Res. 2016, 97, 19-25. [CrossRef] [PubMed]

15. Li, L.; Pan, G. A universal method for flocculating harmful algal blooms in marine and fresh waters using modified sand. Environ. Sci. Technol. 2013, 47, 4555-4562. [CrossRef] [PubMed]

16. Chen, J.; Pan, G. Harmful algal blooms mitigation using clay/soil/sand modified with xanthan and calcium hydroxide. J. Appl. Phycol. 2012, 24, 1183-1189. [CrossRef]

17. Dai, L.; Pan, G. The effects of red soil in removing phosphorus from water column and reducing phosphorus release from sediment in Lake Taihu. Water Sci. Technol. 2014, 69, 1052-1058. [CrossRef]

18. Pan, G.; Dai, L.; Li, L.; He, L.; Li, H.; Bi, L.; Gulati, R.D. Reducing the recruitment of sedimented algae and nutrient release into the overlying water using modified soil/sand flocculation-capping in eutrophic lakes. Environ. Sci. Technol. 2012, 46, 5077-5084. [CrossRef] [PubMed]

19. Li, H.; Pan, G. Simultaneous removal of harmful algal blooms and microcystins using microorganism-and chitosan-modified local soil. Environ. Sci. Technol. 2015, 49, 6249-6256. [CrossRef] [PubMed]

20. Pan, G.; Yang, B.; Wang, D.; Chen, H.; Tian, B.-H.; Zhang, M.-L.; Yuan, X.-Z.; Chen, J. In-lake algal bloom removal and submerged vegetation restoration using modified local soils. Ecol. Eng. 2011, 37, 302-308. [CrossRef]

21. Zhang, H.; Shang, Y.; Lyu, T.; Chen, J.; Pan, G. Switching harmful algal blooms to submerged macrophytes in shallow waters using geo-engineering methods: Evidence from a $15 \mathrm{~N}$ tracing study. Environ. Sci. Technol. 2018, 52, 11778-11785. [CrossRef]

22. Pan, G.; He, G.; Zhang, M.; Zhou, Q.; Tyliszczak, T.; Tai, R.; Guo, J.; Bi, L.; Wang, L.; Zhang, H. Nanobubbles at hydrophilic particle-Water interfaces. Langmuir 2016, 32, 11133-11137. [CrossRef] [PubMed]

23. Wang, L.; Miao, X.; Pan, G. Microwave-induced interfacial nanobubbles. Langmuir 2016, 32, 11147-11154. [CrossRef]

24. Zhang, H.; Lyu, T.; Bi, L.; Tempero, G.; Hamilton, D.P.; Pan, G. Combating hypoxia/anoxia at sediment-water interfaces: A preliminary study of oxygen nanobubble modified clay materials. Sci. Total Environ. 2018, 637, 550-560. [CrossRef]

25. Wang, L.; Miao, X.; Lyu, T.; Pan, G. Quantification of oxygen nanobubbles in particulate matters and potential applications in remediation of anaerobic environment. Am. Chem. Sci. Omega 2018, 3, 10624-10630. [CrossRef]

26. Shi, W.; Pan, G.; Chen, Q.; Song, L.; Zhu, L.; Ji, X. Hypoxia remediation and methane emission manipulation using surface oxygen nanobubbles. Environ. Sci. Technol. 2018, 52, 8712-8717. [CrossRef] [PubMed]

27. Conley, D.J.; Carstensen, J.; Vaquer-Sunyer, R.; Duarte, C.M. Ecosystem thresholds with hypoxia. Hydrobiologia 2009, 629, 21-29. [CrossRef]

28. APHA. Standard Methods for the Examination of Water and Wastewater; American Public Health Association (APHA): Washington, DC, USA, 2005.

29. Hu, H. The Freshwater Algae of China: Systematics, Taxonomy and Ecology; Science Press: Beijing, China, 2006. 
30. Oladoja, N.A.; Pan, G. Modification of local soil/sand with Moringa oleifera extracts for effective removal of cyanobacterial blooms. Sustain. Chem. Pharm. 2015, 2, 37-43. [CrossRef]

31. Douglas, G.; Hamilton, D.; Robb, M.; Pan, G.; Spears, B.; Lurling, M. Guiding principles for the development and application of solid-phase phosphorus adsorbents for freshwater ecosystems. Aquat. Ecol. 2016, 50, 385-405. [CrossRef]

32. Wang, L.; Pan, G.; Shi, W.; Wang, Z.; Zhang, H. Manipulating nutrient limitation using modified local soils: A case study at Lake Taihu (China). Water Res. 2016, 101, 25-35. [CrossRef]

33. Yuan, X.-Z.; Pan, G.; Chen, H.; Tian, B.-H. Phosphorus fixation in lake sediments using LaCl3-modified clays. Ecol. Eng. 2009, 35, 1599-1602. [CrossRef]

34. Xu, R.; Zhang, M.; Mortimer, R.J.; Pan, G. Enhanced phosphorus locking by novel lanthanum/aluminum-hydroxide composite: Implications for eutrophication control. Environ. Sci. Technol. 2017, 51, 3418-3425. [CrossRef]

35. Scheffer, M.; Carpenter, S.; Foley, J.A.; Folke, C.; Walker, B. Catastrophic shifts in ecosystems. Nature 2001, 413, 591-596. [CrossRef]

36. Pan, G.; Krom, M.D.; Herut, B. Adsorption-desorption of phosphate on airborne dust and riverborne particulates in East Mediterranean seawater. Environ. Sci. Technol. 2002, 36, 3519-3524. [CrossRef]

37. Parkyn, S.M.; Hickey, C.W.; Clearwater, S.J. Measuring sub-lethal effects on freshwater crayfish (Paranephrops planifrons) behaviour and physiology: Laboratory and in situ exposure to modified zeolite. Hydrobiologia 2011, 661, 37-53. [CrossRef]

38. Wang, Z.; Zhang, H.; Pan, G. Ecotoxicological assessment of flocculant modified soil for lake restoration using an integrated biotic toxicity index. Water Res. 2016, 97, 133-141. [CrossRef] [PubMed]

39. Kong, M.; Chen, X.G.; Xing, K.; Park, H.J. Antimicrobial properties of chitosan and mode of action: A state of the art review. Int. J. Food Microbiol. 2010, 144, 51-63. [CrossRef]

40. Mucci, M.; Noyma, N.P.; de Magalhaes, L.; Miranda, M.; van Oosterhout, F.; Guedes, I.A.; Huszar, V.L.; Marinho, M.M.; Lürling, M. Chitosan as coagulant on cyanobacteria in lake restoration management may cause rapid cell lysis. Water Res. 2017, 118, 121-130. [CrossRef]

(C) 2019 by the authors. Licensee MDPI, Basel, Switzerland. This article is an open access article distributed under the terms and conditions of the Creative Commons Attribution (CC BY) license (http://creativecommons.org/licenses/by/4.0/). 